\title{
Development of duplex real time PCR for quick detection of Cryptosporidia in goats
}

2 Atul Kumar Sharma ${ }^{\mathrm{a}, \mathrm{b}}$, K. Gururaj ${ }^{\mathrm{a}}$,, Rama Sharma $^{\mathrm{b}}$, Anjana Goel ${ }^{\mathrm{b}}$, Souvik Paul ${ }^{\mathrm{c}}$, Dinesh Kumar

3 Sharma ${ }^{\mathrm{a}}$

$4{ }^{a}$ Division of Animal Health, ICAR-Central Institute for research on Goats, Makhdoom, Farah

5 (P.O.), Mathura-281122, Uttar Pradesh

$6 \quad{ }^{b}$ Department of Biotechnology GLA University Mathura-281122, Uttar Pradesh

$7 \quad *$ Corresponding author details: Senior Scientist, Microbiology Laboratory, ${ }^{\mathrm{a} D i v i s i o n}$ of Animal

8 Health, ICAR-Central Institute for research on Goats, Makhdoom, Farah (P.O.), Mathura-

9 281122, Uttar Pradesh, Corresponding author Email: guruvet@gmail.com

10

11

12

13

14

15

16

\section{Abstract}

Cryptosporidium spp. is the most important foodborne and waterborne pathogens and the leading cause of mortality from foodborne and waterborne gastrointestinal disease. In neonates of domestic animals it is associated with consistent diarrhoea and dehydration. Cryptosporidium infection begins with the ingestion of sporulated oocytes disseminated by carrier animals that consistently contaminate the environment. Many diagnostic tests are available including microscopy, antigen trap ELISA, but none of the diagnostic tests available currently cannot differentiate between active and passive infection in the host. In the current study, to address this challenge an mRNA based duplex TaqMan ${ }^{\circledR}$ probe PCR (dRT-qPCR) was developed to target the Cryptosporidium oocyst wall protein (COWP) gene and 18ssu rRNA gene in a single tube that can detect metabolically active Cryptosporidial oocysts. The mRNA transcripts are the direct indicator of any actively replicating cell and it will help decipher the active stages of its lifecycle in host. This diagnostic assay was standardized by computing transcript copy number-based limit 
23 of detection. For COWP and 188ssu rRNA genes the limit of detection was $7.08 \times 10^{04}$ and

$245.95 \times 10^{05}$ respectively. During active infections the oocyst wall protein will be active and so its

25 COWP gene transcripts will act as marker for active infection. While transcripts for 18SSU

26 rRNA are constitutively expressing in Cryptosporidial life cycle. This current diagnostic assay

27 will be a quantitative marker that will help assess active stages of Cryptosporidium infection in

28 neonates. The disease dynamics will help better understand to formulate the control strategies

29 and contain infection among the healthy animals.

30 Importance:

31 Cryptosporidiosis is an important neonatal disease affecting goats causing diarrhoea, dehydration

32 and stunted growth. For diagnosing this condition, many diagnostic tests are available including

33 microscopy, immunological tests, but none of the diagnostic tests available currently can

34 differentiate between active and passive infection in the host. The mRNA transcripts are the

35 direct indicator of any actively replicating cell and especially in intracellular parasites it will help

36 decipher the infective stages of a lifecycle in the host, and hence the test was developed in a

37 reverse transcriptional format in a duplex mode. The currently developed diagnostic assay for

38 cryptosporidiosis was evaluated for sensitivity using Limit of detection (LOD). This diagnostic

39 test will act as a quantitative marker to aid in detecting active stages of Cryptosporidium

40 infection in neonatal goats and will eventually lead to better control strategies for managing

41 cryptosporidial infections in the future.

42 Keywords: Cryptosporidium, neonatal goat, duplex PCR, COWP gene, live and dead oocyst

43 differentiation, dRT-qPCR 
44 Cryptosporidiosis disease caused by the intracellular, extra-cytoplasmic protozoan parasite, 45 belong to the phylum Apicomplexa. Cryptosporidiosis is the primary cause of chronic diarrhea among immunocompromised patients especially in children suffering from HIV, AIDS-defining

47 illness because of its high association with mortality (1-4). Cryptosporidium oocysts are transmitted via faecal-oral route, either direct or indirect contact with contaminated or ingestion

49 of contaminated water and food $(5,6)$. In domestic animals, the disease is economically important as it affects the growth rate due to persistent clinical diarrhoea especially in neonates.

51 The disease mainly affects the goat kids, calves and lambs, while the adult animals act as silent

52 carrier disseminating the infection $(7,8)$. The animals upon infection with Cryptosporidium oocysts, excystation occur and then subsequently release four sporozoites. Sporozoites adhere to

54 the epithelial cells of ileum and incorporated into the parasitophorous vacuole, and the feeder organelle present in all intracellular stages of Cryptosporidium acts as interface between hostparasite cells. After feeder organelle development, sporozoite forms a trophozoite and becomes

57 more spherical in shape, asexual reproduction begins and develops the type I meront and release merozoites, which immediately re-infect the host. Again type I meront begins the asexual

59 reproduction and forms the type II meront, which release the four merozoites and start the sexual reproductive cycle. Merozoites capture the host cells and transform it into the macrogamonts or

61 microgamonts, which release the microgametes and macrogametes. Microgametes fertilise the 62 macrogametes and produces a zygote, which differentiate into four sporozoites, develops as 63 oocysts and released in lumen and again re-infect the host from thin-walled oocysts. Thin-walled 64 oocysts are shed in stools and act as source of infection for other hosts, and are also responsible 65 for the auto infection in the host. Whereas, thick-walled oocysts excreted by infected host are 66 very resistant to $\mathrm{pH}$, humidity, temperature etc. and can survive several months (9-12). 
67 Diagnosis still plays a very important role because in neonatal animals many other diseases like colibacillosis, rotaviral diarrhoea caused by group A rotavirus (GARV) and bovine corona virus $(\mathrm{BCoV})$ occurs commonly and there is a need to differentiate them or identify them collectively

70 in case of mixed infection. While coccidiosis occurs in weaned animals in later stages that might

71 perplex in the proper diagnosis. Microscopy is an excellent tool and can be highly specific but

72 requires expertise and experience in identification of the weak acid fast round oocysts from other

73 artefacts similar to them. Besides conventional microscopy and staining, molecular diagnostic

74 approaches like PCR are also gaining momentum Molecular diagnostic assays are usually

75 regarded as more sensitive compared to microscopy and serological diagnosis in human and

76 animals for the detection of Cryptosporidium in several studies (13-23). The molecular assays

77 are determined by the factors like stage of life cycle/infection as well as method of nucleic acid

78 extraction for targeting the Cryptosporidium spp. ( 24-27).

79 The already available diagnostic assays can only detect the presence or absence of Cryptosporidium in a qualitative manner, and there is no scope to decipher the

81 metabolically/transcriptionally active oocysts from passive ones. Hence, a robust technique is

82 required that can able to differentiate the active oocysts from dead oocyst in passive infection.

83 In detail, the main aim of this study is to develop and standardize an mRNA based

84 Cryptosporidium spp.-specific real-time PCR assay using two important target genes viz. 18

85 small subunit ribosomal RNA (18SSU rRNA) and Cryptosporidium oocyst wall (COWP). The

86 18ssu rRNA gene is highly abundant in terms of genomic copies and it has high transcripts that

87 can increase the sensitivity of the assay, while the COWP is available only in transcriptionally

88 active live cryptosporidial oocysts. (13-23, 28-31). 
89 Hence, in the current study we report an mRNA based TaqMan® probe duplex real time PCR

90 that can able to detect the metabolically active Cryptosporidium oocysts from dead oocysts in

91 passively infected animals

92 RESULTS

93 Microscopic identification of Cryptosporidium

Cryptosporidium suspected faecal smear that were stained by the modified Ziehl-Neelsen

95 staining ( $\mathbf{m Z N}$ staining) were examined by microscopy at 100x magnification under immersion oil, where 39 samples were found positive out of 61 suspected samples which are collected form

97 neonatal goat kids. The oocysts appeared as acid fast round bodies against a blue-green 98 background (Fig.1).

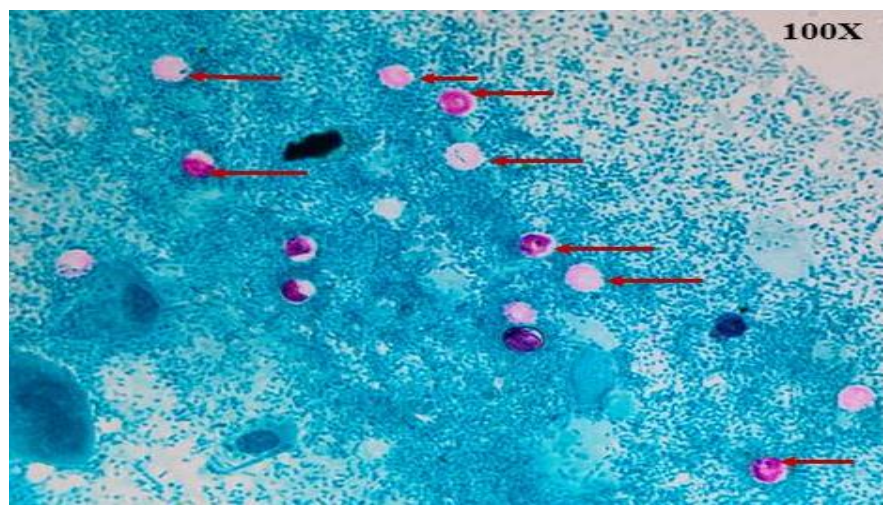

FIG 1 Faecal smear stained from clinically affected Cryptosporidiosis disease animal using modified Ziehl Neelsons' technique showing Cryptosporidium oocysts (Indicating Arrows)

The conventional PCR reactions for newly designed primers viz., COWP and $18 s s u$ rRNA were 

controls did not generate any visible amplicons in this technique.

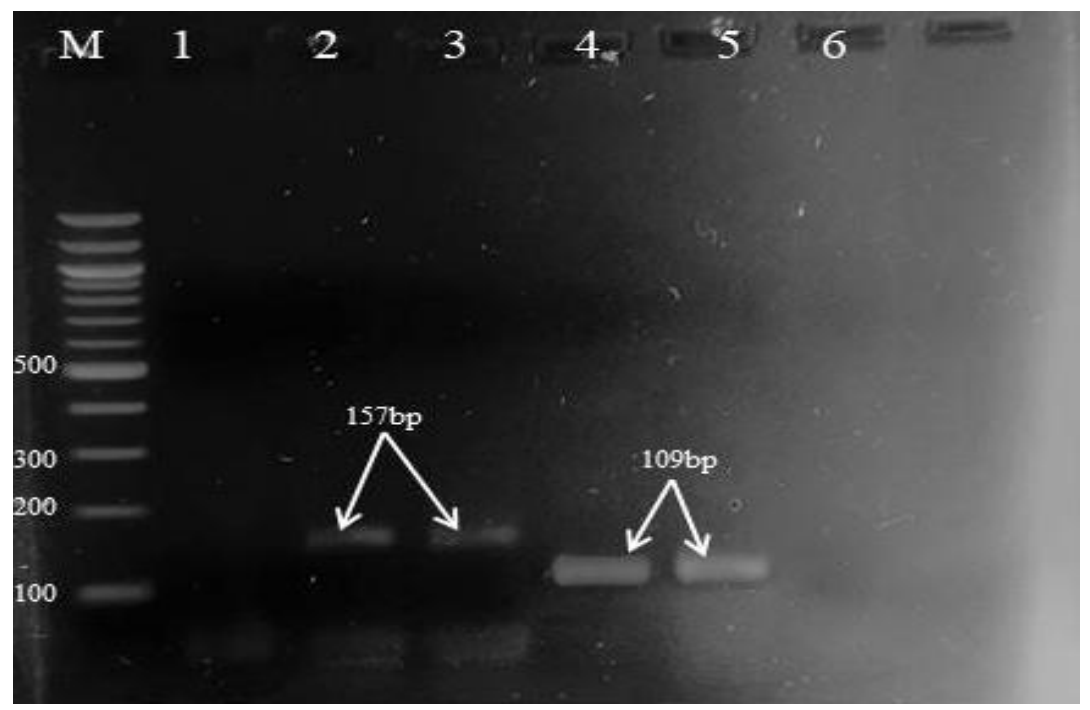

FIG 2 Gel-electrophoresis of conventional PCR targeting COWP and 18ssurRNA genes using newly designed primers. Lane M: 100bp ladder, Lane 1 NTC, 2\&3 Positive samples COWP FAM (157bp), 4\&5 positive sample for $18 s s u$ rRNA-HEX (109bp), Lane 6: NTC (no template

111 control).

\section{DNA duplex PCR for Cryptosporidium}

After verifying the workability of the newly designed primers by conventional PCR, the same set using template DNA positive for cryptosporidium. Signals were produced in the form of $\mathrm{Cq}$ for both the COWP (FAM) and 18ssu rRNA (HEX) as marked as visible sigmoid curve highlighted

117 as blue and green respectively (FIG 3). The Cq and RFU values for COWP and $18 s s u$ rRNA 118 generated in duplex DNA PCR are provided in table below (Table 7). While the no template controls (NTC) produced mean Cq for COWP and 18ss rRNA of 33.32 and 35.88 respectively which were above the threshold cut-off cq for their respective genes and hence are negative. 


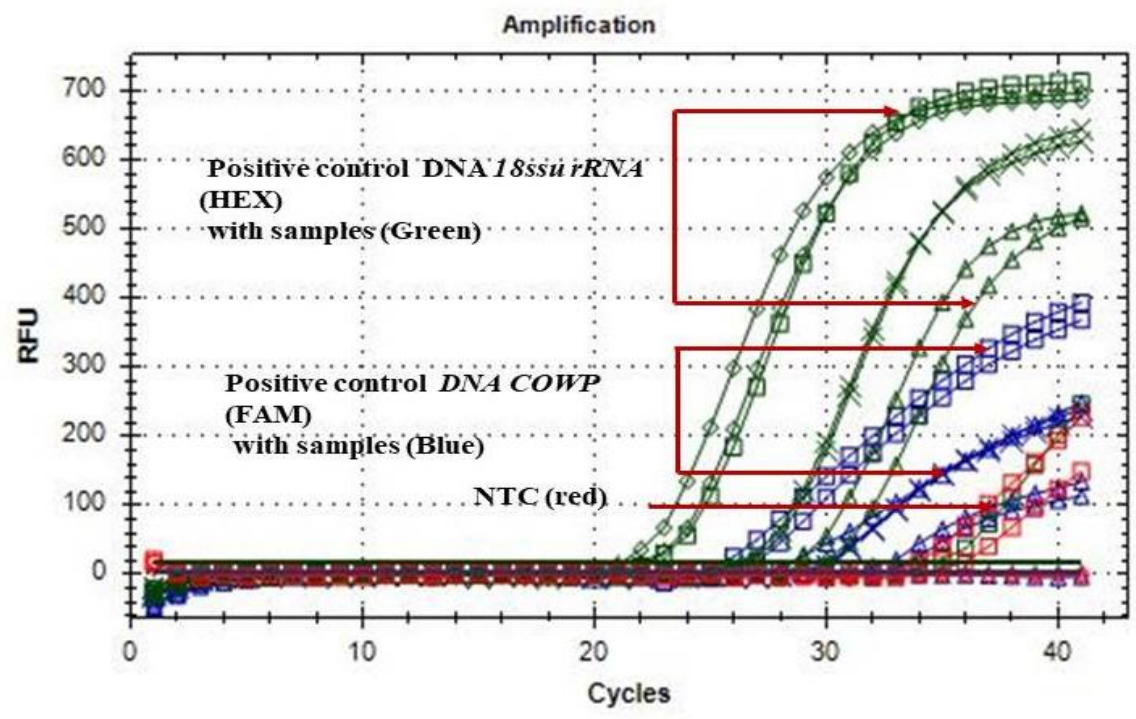

122 FIG 3 DNA duplex PCR for COWP (FAM) and 18ssu rRNA (HEX) gene of Cryptosporidium

123 from positive DNA with NTC.

124 Table 1 Mean $\mathrm{Cq}$ and RFU values for COWP and 18ssu rRNA for dRT-qPRC

\begin{tabular}{|c|c|c|c|c|c|}
\hline S.No & Sample & COWP $(\mathbf{C q}$ & Mean & 18ssu rRNA & RFU values \\
& & Mean colored & RFU & Cq Mean & for 18ssu \\
& & blue $)$ & values for & colored & rRNA \\
& & & COWP & green $)$ & \\
\hline 1. & Positive control & 24.84 & 393.56 & 21.58 & 696.75 \\
\hline 2. & Sample 1 & 23.50 & 248.24 & 28.43 & 713.35 \\
\hline 3. & Sample 2 & 28.31 & 239.46 & 26.42 & 626.51 \\
\hline 4. & Sample 3 & 13.64 & 113.77 & 33.69 & 515.92 \\
\hline 5. & NTC & 33.32 & 1.90 & 35.88 & 149.48 \\
\hline
\end{tabular}

125 
Probe and Primer Standardization for reverse transcription duplex TaqMan probe real

After observing the workability of the duplex TaqMan® probe real time PCR using DNA template, we further worked on the optimal concentrations of probe and primers by titration for cDNA (prepared from faecal RNA positive for Cryptosporidium both by microscopy and conventional PCR). Based on the titrations, the primer or probe concentration that has produced the best RFU value and the $\mathrm{Cq}$ values were taken as the optimal concentration. So as per the results (Fig.4), for $C O W P$ gene the optimal primer and probe concentrations were 8picomoles

134 (for both forward and reverse primers) and 10picomoles respectively. Similarly, the optimal 135 primer and probe concentrations for 18ssurRNA are 4picomoles (each of the primers) and 4pmol 136 for probe. Henceforth these standardized concentrations were used for assay of unknown 137 samples suspected for Cryptosporidium throughout the study for the current diagnostic 138 technique.

139 Table 2 primer probe optimization for duplex mRNA based TaqMan probe real time PCR

\begin{tabular}{|l|c|c|c|}
\hline \multirow{3}{*}{ S.N. } & Genes & \multicolumn{2}{|c|}{ Final concentration used } \\
\hline \multirow{3}{*}{1.} & \multirow{3}{*}{ COWP (FAM) } & Forward Primer & $8 \mathrm{pmol}$ \\
\cline { 3 - 4 } & & Reverse Primer & $8 \mathrm{pmol}$ \\
\cline { 3 - 4 } & $18 s s u$ rRNA (HEX) & Probe & $10 \mathrm{pmol}$ \\
\hline \multirow{3}{*}{2.} & & Forward Primer & $4 \mathrm{pmol}$ \\
\cline { 3 - 4 } & & Reverse Primer & $4 \mathrm{pmol}$ \\
\cline { 3 - 4 } & & & $4 \mathrm{pmol}$ \\
\hline
\end{tabular}




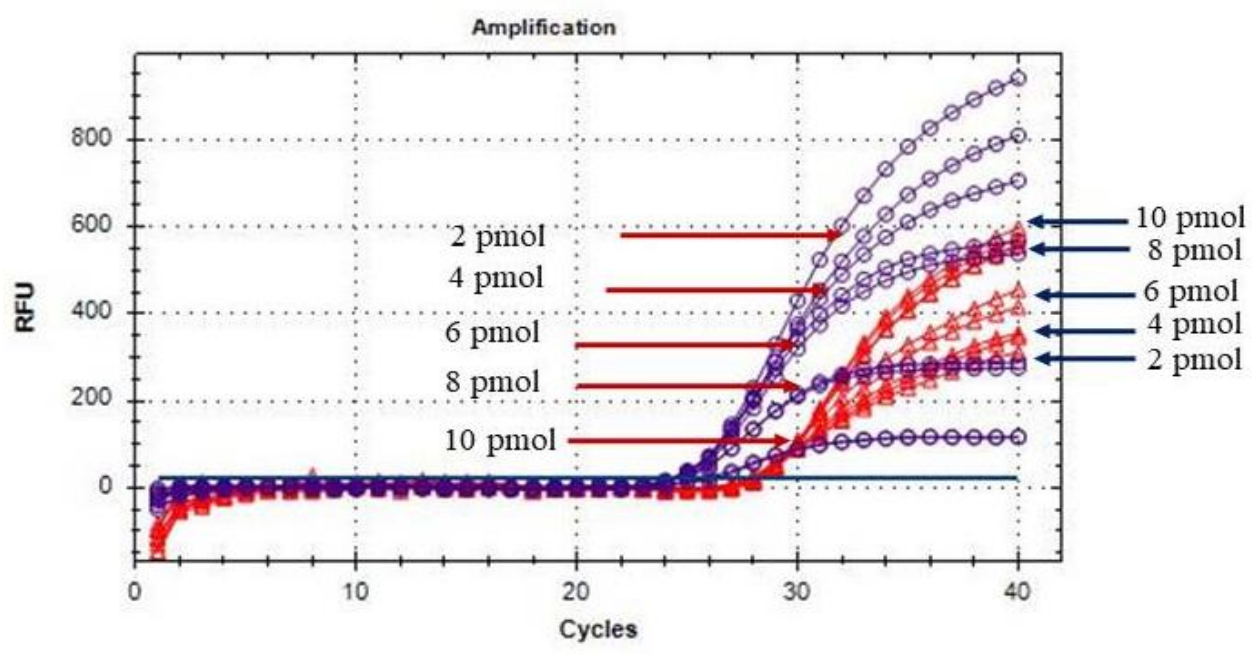

142 FIG 4: Titration of Primers and probes for COWP (FAM) indicating by red colour and 18ssu rRNA (HEX) indicating by blue colour in duplex PCR method

Limit of Detection (LODs) using COWP (FAM) and 18ssu rRNA (HEX), genes as simplex and duplex modes by reverse transcription TaqMan® probe real time PCR assay for respective purified amplicons of genes viz. COWP and $18 s s u$ rRNA, we performed limit of detection by serial dilutions assay in both simplex and duplex modes using the currently

151 developed TaqMan probe real time PCR assay. Initially standard curves were generated for LOD by simplex assay.

153 Table 3 Concentrations used for serial dilutions in simplex LOD TaqMan probe assay

\begin{tabular}{|c|c|c|c|c|c|}
\hline S.No. & Gene & Stock & Starting & Ending & No. of \\
& & concentration & concentration & concentration & dilutions \\
\hline
\end{tabular}




\begin{tabular}{|c|c|c|c|c|c|}
\hline 1. & COWP & $91 \mathrm{ng} / \mu \mathrm{l}$ & $5.37 \times 10^{11}$ & $5.37 \times 10^{06}$ & 06 \\
\hline 2. & 18 ssu rRNA & $144 \mathrm{ng} / \mu 1$ & $1.22 \times 10^{12}$ & $1.22 \times 10^{07}$ & 06 \\
\hline
\end{tabular}

155 The sensitivity of the assay was based on the copy numbers ranged from $5.37 \times 10^{11}$ to $5.37 \times 10^{06}$ 156 for $C O W P(\mathrm{FAM})$ and $1.22 \times 10^{12}$ to $1.22 \times 10^{07}$ for $18 s s u$ rRNA (HEX) separately in simplex 157 mode. The standard curve showed a linear curve over these dilutions to making the range of 158 detection (ROD) for respective genes. The LOD for the targets COWP-FAM and 18ssu rRNA159 HEX were $5.37 \times 10^{06}$ and $1.22 \times 10^{07}$ copies respectively.
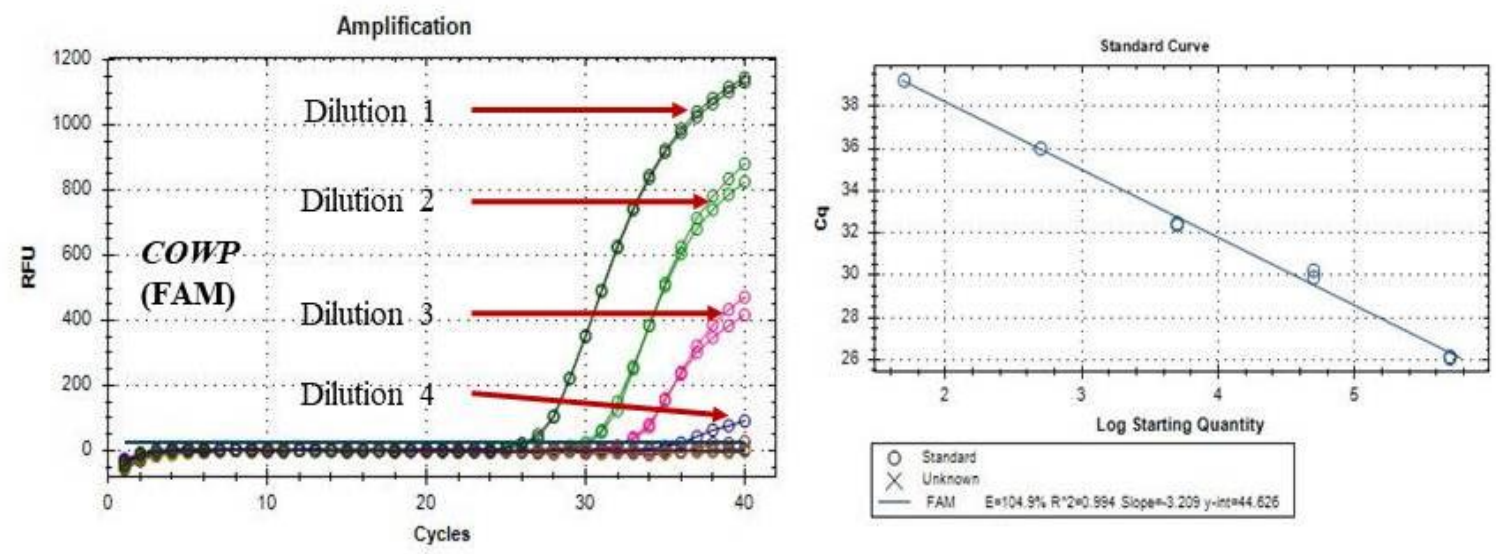

FIG 5a Amplification plot of serially diluted Cryptosporidium amplicon of COWP-FAM gene, descending concentrations (by a magnitude of $\log _{10}$ ) ranging from $5.37 \times 10^{11}$ (Dilution 1 ) to $7.08 \times 10^{05}$ (Dilution6) for determination of LOD by TaqMan® probe based real-time PCR assay. 5b The standard curve for a 10-fold serial dilution series (with linearity from Dilution 1 to dilution 4) plotted as the threshold cycle on the Y-axis, against the target concentration of cDNA per assay $(\mathrm{X}$-axis) with $\mathrm{E}$ value $=104.9 \%$, correlation coefficient $(\mathrm{R} 2)=0.994$, slope $=-3.209$ and $\mathrm{Y}$ intercept $=44.626$ 

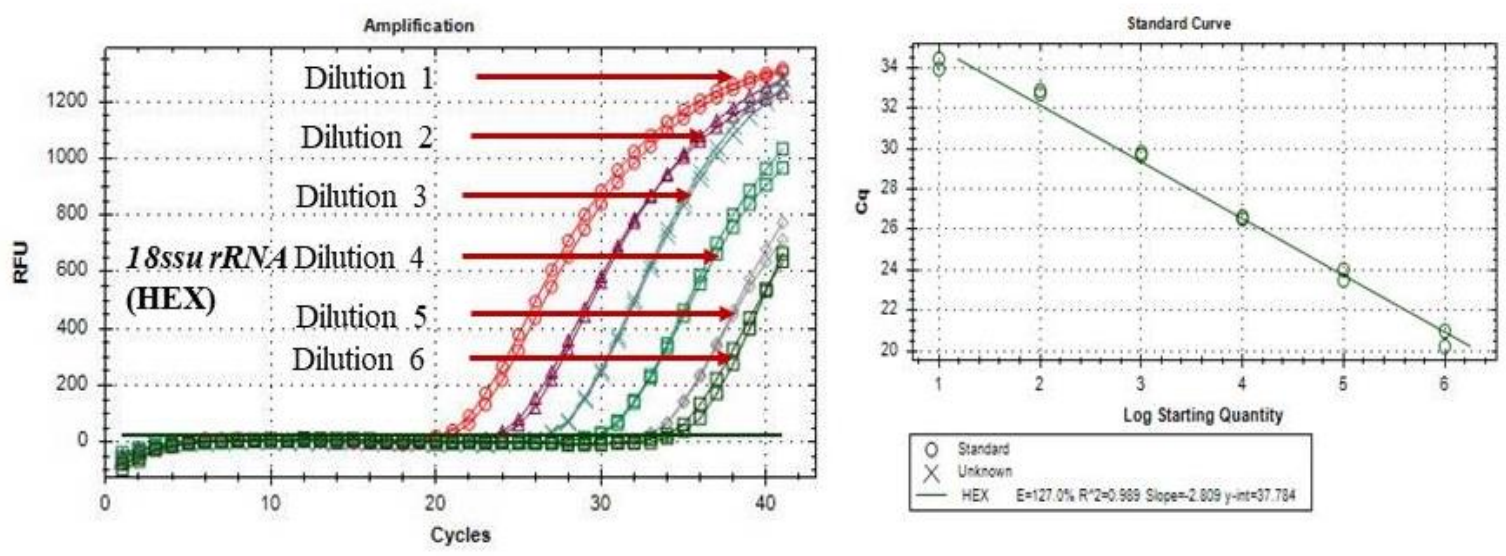

FIG 6a Amplification plot of serially diluted Cryptosporidium amplicon of $18 s s u$ rRNA- HEX gene, descending concentrations (by a magnitude of $\log _{10}$ ) ranging from $1.22 \times 10^{12}$ (dilution cDNA per assay $(\mathrm{X}$-axis $)$ with $\mathrm{E}$ value $=127.0 \%$, correlation coefficient $(\mathrm{R} 2)=0.989$, slope $=$

\section{Limit of detection of target genes using duplex mode}

177 The sensitivity of duplex assay was based on the copy numbers ranged from $7.08 \times 10^{10}$ to $7.08 \times 10^{05}$ for $C O W P(\mathrm{FAM})$ and $5.95 \times 10^{11}$ to $5.95 \times 10^{06}$ for $18 s s u$ rRNA (HEX). The standard curve showed a linear curve over these dilutions to making the range of detection (ROD) for respective genes. The LOD for the targets COWP-FAM and $18 s s u$ rRNA- HEX were $7.08 \times 10^{05}$ and $5.95 \times 10^{06}$ copies respectively.

Table 4 Concentrations used for serial dilutions in Duplex LOD TaqMan probe assay

\begin{tabular}{|l|l|l|l|l|l|l|}
\hline S.No. & Gene & Stock & Starting & Ending & No. of & Limit of detection \\
\hline
\end{tabular}


bioRxiv preprint doi: https://doi org/10.1101/2022 $0223.481731 \cdot$ this version posted February 25,2022 The copyright holder for this preprint (which was not certified by peer review) is the author/funder, who has granted bioRxiv a license to display the preprint in perpetuity. It is made available under aCC-BY-NC-ND 4.0 International license.

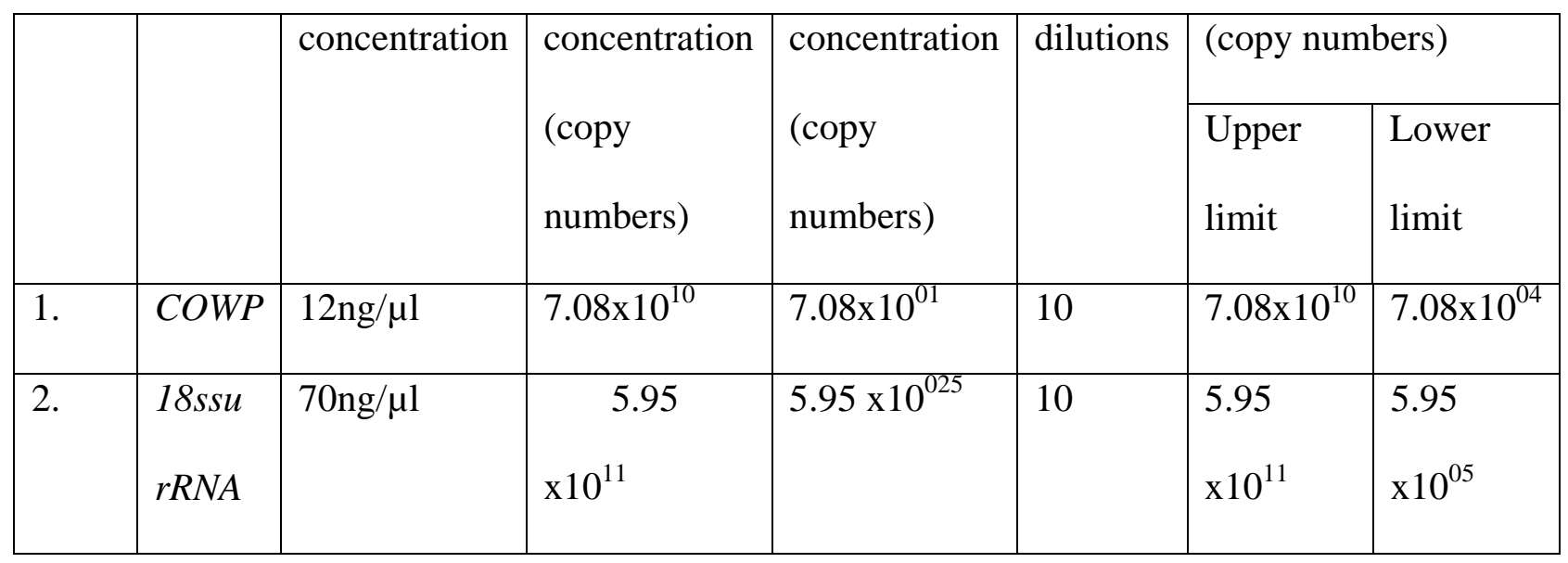

183
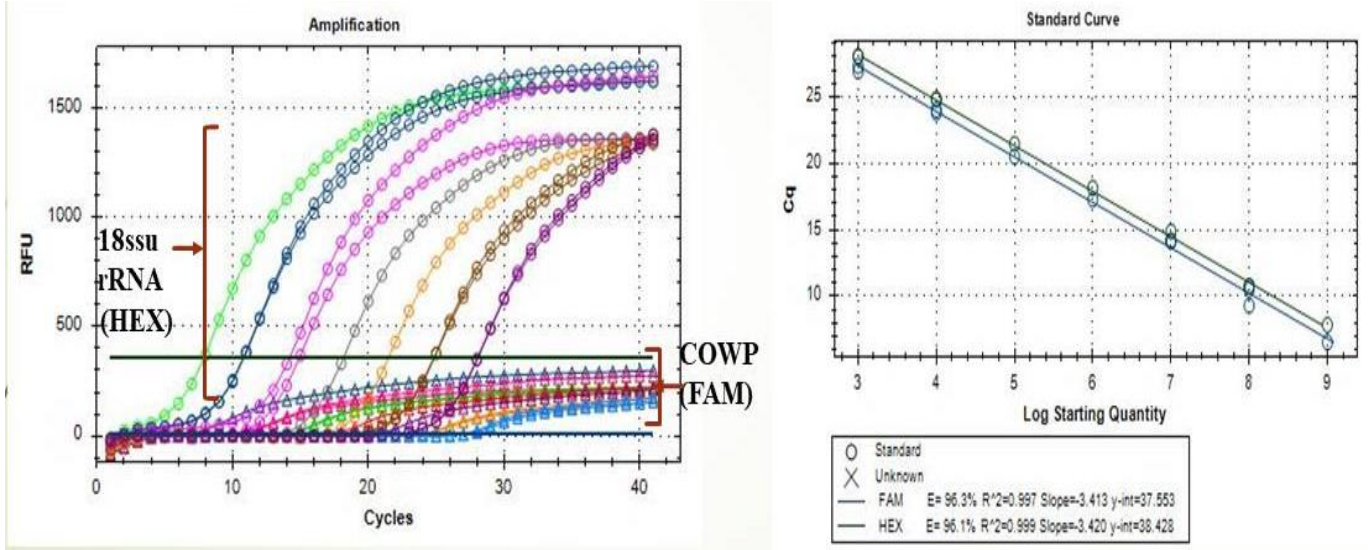

a.
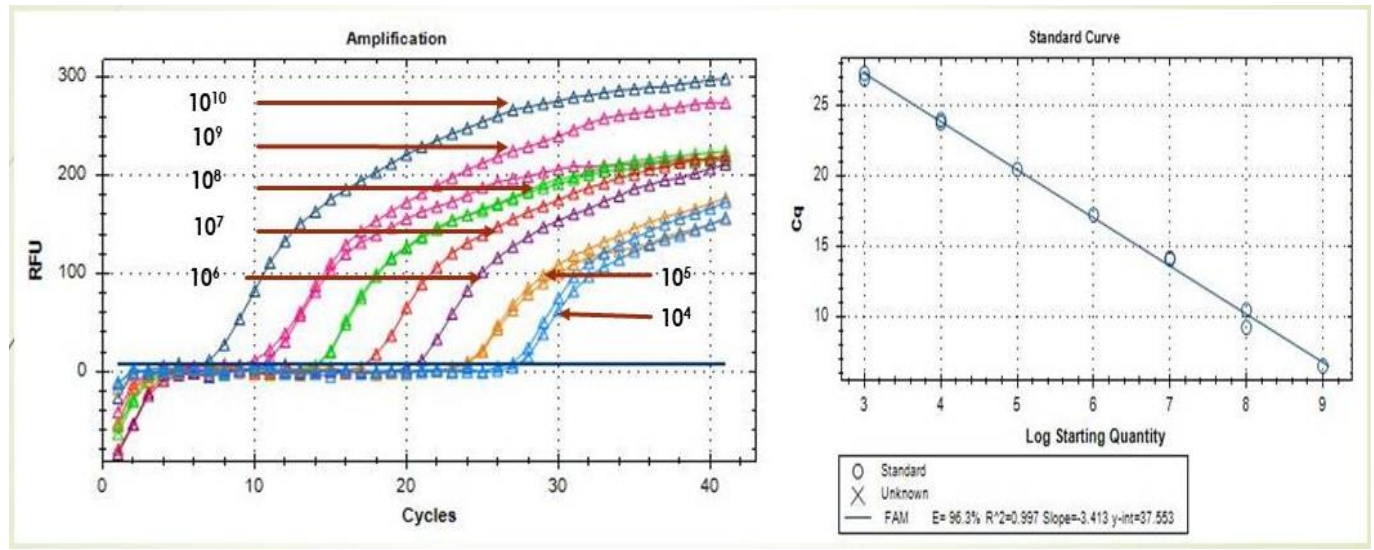

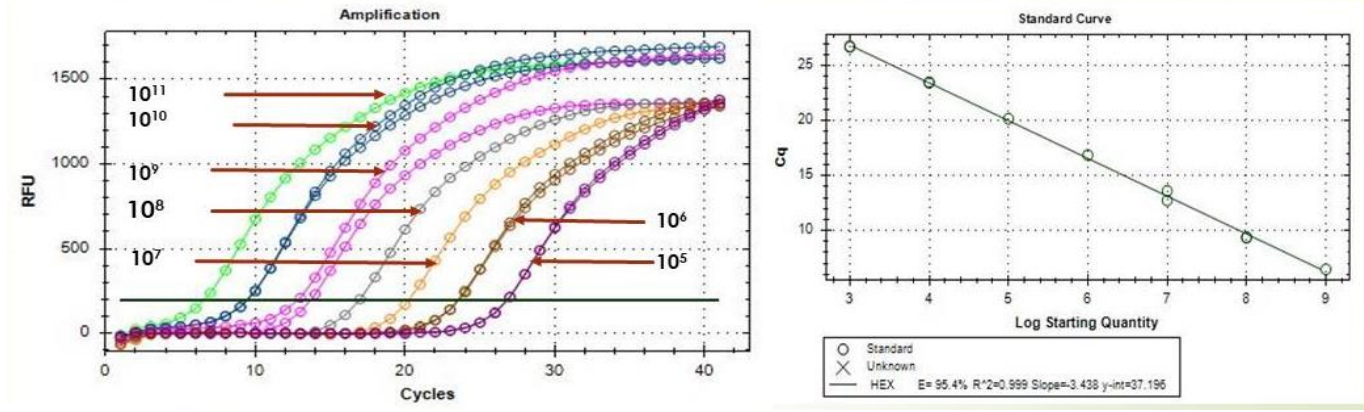

FIG 7a Duplex reverse transcription TaqMan ${ }^{\circledR}$ Probe Real time PCR for COWP (FAM) and

18ssu rRNA gene of Cryptosporidium from positive cDNA with standard curve, 7b Extracted rRNA gene only from the duplex real time PCR data. qPCR)

\section{Relative quantification}

The samples including unknown (clinically positive and cryptosporidia infected < 1 month olf goat kids) and control (Carrier status apparently healthy <1month goat kid positive for crytosporidial oocyst by microscopy) were assayed using Cryptosporidal dRT-qPCR along with

Table 5 Relative quantification of COWP and $18 s s u$ rRNA by dRT-qPCR

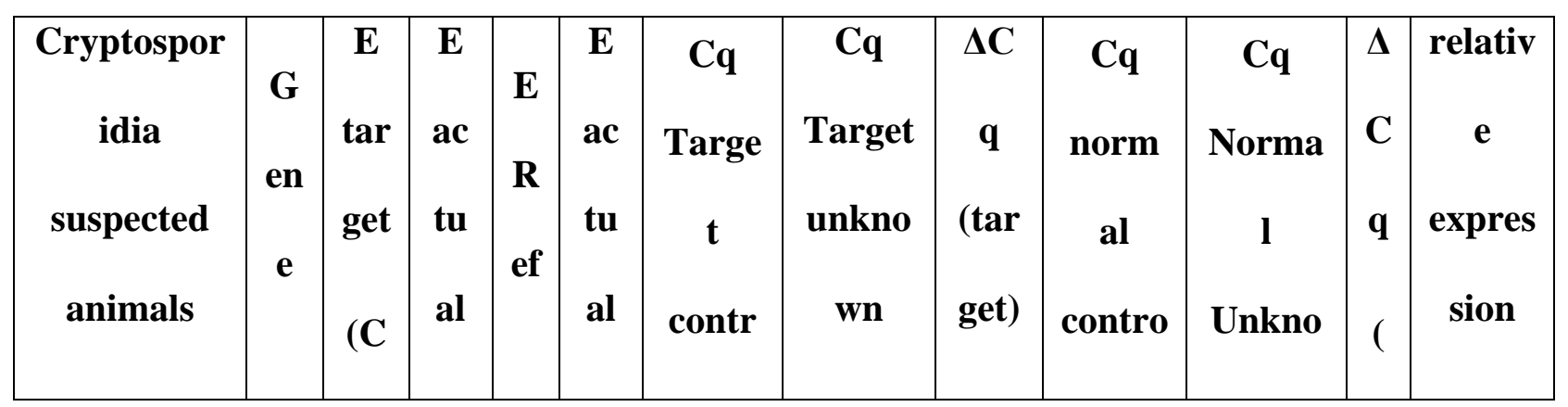




\begin{tabular}{|c|c|c|c|c|c|c|c|c|c|c|c|c|}
\hline & & $\begin{array}{l}\text { O } \\
\mathbf{W} \\
\text { P) }\end{array}$ & & & & ol & & & I & wn & $\begin{array}{l}\mathbf{R} \\
\mathbf{e} \\
\mathbf{f})\end{array}$ & \\
\hline Animal 1 & $\begin{array}{c}\mathbf{C} \\
\mathbf{O} \\
\mathbf{W} \\
\mathbf{P}\end{array}$ & $\begin{array}{c}96 . \\
3\end{array}$ & $\begin{array}{c}1 . \\
96 \\
3\end{array}$ & $\begin{array}{l}6 . \\
1\end{array}$ & $\begin{array}{c}1 . \\
96 \\
1\end{array}$ & 32.53 & 28.18 & 4.35 & 26.22 & 24.83 & $\begin{array}{l}1 . \\
3 \\
9\end{array}$ & $\begin{array}{l}7.3732 \\
58295\end{array}$ \\
\hline Animal 2 & $\begin{array}{c}\mathbf{C} \\
\mathbf{O} \\
\mathbf{W} \\
\mathbf{P}\end{array}$ & $\begin{array}{c}96 . \\
3\end{array}$ & $\begin{array}{c}1 . \\
96 \\
3\end{array}$ & $\begin{array}{l}6 . \\
1\end{array}$ & $\begin{array}{c}1 . \\
96 \\
1\end{array}$ & 29.58 & 28.24 & 1.34 & 29.63 & 24.6 & $\begin{array}{l}5 . \\
0 \\
3\end{array}$ & $\begin{array}{l}0.0834 \\
35506\end{array}$ \\
\hline Animal 3 & $\begin{array}{c}\mathbf{C} \\
\mathbf{O} \\
\mathbf{W} \\
\mathbf{P}\end{array}$ & $\begin{array}{c}96 . \\
3\end{array}$ & $\begin{array}{c}1 . \\
96 \\
3\end{array}$ & 6. & $\begin{array}{c}1 . \\
96 \\
1\end{array}$ & 29.58 & 27.98 & 1.6 & 29.63 & 24.42 & $\begin{array}{l}5 . \\
2 \\
1\end{array}$ & $\begin{array}{c}0.0880 \\
77345\end{array}$ \\
\hline Animal 4 & $\begin{array}{c}\mathbf{C} \\
\mathbf{O} \\
\mathbf{W} \\
\mathbf{P}\end{array}$ & $\begin{array}{c}96 . \\
3\end{array}$ & $\begin{array}{c}1 . \\
96 \\
3\end{array}$ & $\begin{array}{l}6 . \\
1\end{array}$ & $\begin{array}{c}1 . \\
96 \\
1\end{array}$ & 38.24 & 27.73 & $\begin{array}{c}10.5 \\
1\end{array}$ & 29.63 & 24.48 & $\begin{array}{l}5 . \\
1 \\
5\end{array}$ & $\begin{array}{l}37.353 \\
62387\end{array}$ \\
\hline
\end{tabular}




\section{Discussion}

202

203

204

205

206

207

208

209

210

211

212

213

214

215

216

217

218

219

220

221

222

223

Cryptosporidiosis is an important disease, which causes the diarrheal illness in neonatal animals associated with other diarrheal pathogens or as alone (32). However, it is difficult to diagnose cryptosporidiosis alone from other major etiologies of neonatal diarrhoea complex in neonatal animals including E.coli, Group A Rotavirus (GARV) and Bovine corona virus (BCoV). For diagnosing cryptosporidiosis in animals faecal oocyst identification by modified Ziehl-Neelsen staining acid fast staining is a preferred method. Although this method is enough to identify the acid fast oocysts based on colour, shape and size, but it cannot provide details of the active infective stages $(33,34)$. PCR is another method which is highly sensitive, specific and accurate (if standardized), but cannot fix the aforementioned problem of identification of active live oocysts from the passive or dead ones. Hence in the current study we have developed a reverse transcription based TaqMan probe duplex real time PCR for simultaneous detection of two target genes viz., COWP and 18ssu rRNA that would provide better detail on the active and passive stages of cryptosporidial infections in neonatal goats.

Microscopy based detection by modified Ziehl-Neelsen technique was conducted as a preliminary diagnostic screening for presence of cryptosporidial infection in suspected neonatal kids. As observed, this technique could identify 39 cases positive for Cryptosporidiosis out of 61 sampled. Microscopy is only a primary test, but gives an overall idea about the presence of cryptosporidiosis infection in the herd $(21,35-37)$. Therefore, many researchers used mZN technique as gold standard method for the screening of large number of population because it is much easier and non-invasive. Microscopy has certain limitations, like it may not differentiate between the active and passive infections and its sensitivity and specificity is lower as compared to ELISA and PCR $(36,38)$. 
224 Specific diagnostic development with high accuracy and sensitivity is always on the priority to

225 diagnose the each disease. Rapid diagnosis is an important way to overcome the impact of

226 disease and appropriate treatment management. Diagnostic tests are inadequate, serological

227 diagnosis, novel faecal diagnostic analysis and biomarker are require to develop the more

228 accurate and sensitive identification of active Cryptosporidium infection (6).

229 In the present study, primer and probes were newly designed and checked for its working by

230 using conventional PCR, followed by DNA based TaqMan probe duplex PCR. Both the tests

231 identified the presence of Cryptosporidial DNA in the sample targeting the respective genes viz.

$23218 s s u$ rRNA and COWP.

233 Similarly, the Primers and probes were also titrated in simplex and duplex modes at various

234 concentrations and optimised accordingly as given in the results. Eventually the optimal

235 concentrations of primers and probes were used in the dRT-qPCR assay for unknown samples

236 detection, standard curve using copy numbers and relative quantification based cryptosporidial

237 transcriptional response. As per the copy number based standard curve, the RFU is higher for

238 18ssu rRNA because of the abundancy of the transcripts, while for the COWP gene the RFU is

239 relatively lower and is present in clinically affected neonates with active cryptosporidial

240 infection. Hence, there is a scope to decipher the active live cryptosporidal oocysts from the dead

241 ones. Transcriptional activity is present only in live and metabolizing oocysts and their

242 subsequent infective or reproductive stages (gametogony) and hence this assay has the ability to

243 identify and at the same time quantify them based on gene targets used in the current study (34).

244 The 18ssu rRNA is a constitutively expressing gene which is present in all stages of life cycle of

245 cryptosporidia, but transcripts for COWP gene is present only during specific stages and

246 especially the active ones. There is a dearth of information as far as reverse transcriptional qPCR 
247 for cryptosporidiosis is concerned, because many researchers in the past used only DNA based 248 detection method $(29,39)$ and most of them were used rather as a diagnostic for differentiation 249 of C.parvum from C.hominis and other species (13, 30). Similarly sensitivity of detection is 250 another parameter that decides the efficiency of the diagnostic assay, and previously researchers 251 reported as low as 2 oocysts detected using TaqMan probe real time PCR assay and genus 252 specific tests have better sensitivity compared to species specific assays (40). Recently DNA 253 based commercial qPCR were tested for sensitivity and limit of detection, in which FTD stool 254 parasites kit detected 1 and 10 oocyst for $C$. parvum and C.hominis respectively (41), while the 255 in-house developed qPCR from the same research team showed up to 10 oocysts and 1000 256 oocysts for C. parvum and C.hominis respectively. Since most of these studies targeted the 257 genomic DNA, we cannot compare them directly with our dRT-qPCR which is reverse 258 transcriptional and targeting the RNA of the same pathogen. Also the mode of test was duplex in 259 the current study unlike the previous researchers in which simplex mode was followed for LOD 260 and sensitivity assays or multiplex assays involving other species like Giardia.

261 To further understand the dynamics of these two target genes, a relative quantification based 262 dRT-qPCR assay was conducted. In this assay, the fold change was computed for COWP gene 263 which is taken as a gene of interest (GOI) due to its differential expression during infections, 264 while 18ssurRNA was used as a reference gene because of its constitutive expressive nature in 265 cryptosporidial life cycle. Four clinically and microscopically cryptosporidia positive neonatal 266 kids were compared with the control kids which are apparently healthy with no overt clinical 267 signs but positive for cryptosporidia. This was done to actually assess the difference in 268 expression levels of $C O W P$ in these two groups (clinical and carrier) of cryptosporidial positive 
animals. Also there is no logic in comparing the infected and non-infected animals, because here the genes are from the pathogen itself and not actually from the host.

271 Previously, PCR based test has been established for the identification of Cryptosporidium

272 infection with higher sensitivity and specificity as compare to the conventional and other

273 methods which used to identify the cause the infection in gastroenteritis (42-44). PCR based

274 method gives the highly reliable and accurate results compare with faecal- smear microscopy

275 because of cross-contamination from the environment in the direct faecal examination (45).

276 Thus, PCR based test are helpful to identify the species or strain of any pathogens and

277 differentiate the responsible pathogens for causing the diarrheal illness by their epidemiology

278 and clinical manifestation (46). Therefore, this study used mRNA based TaqMan probe real time

279 PCR assay to reliable and new diagnostic tool for detection the Cryptosporidium spp. at different

280 stages of infection and differentiate the active and passive infection in host animal and humans.

281 The mRNA based TaqMan probe real time PCR assay is simple, rapid and self-regulating 282 amplification system with low probability of cross-contamination as compared to other 283 conventional PCR methods (47, 48). This study showed the successful standardization and 284 development mRNA based TaqMan probe assay for targeting the 18ssu rRNA and cowp genes.

\section{Material and Methods}

\section{Sample collection}

287 Diarrheic faecal samples were collected from Jamunapari and Barbari breed of goats from 288 ICAR- CIRG Mathura. Faecal sample were collected as lavage from neonatal kids in 1X sterile 289 PBS by flushing with the aid of sterile syringe (without any needle) through anal orifice (noninvasive method). The faecal lavage was transferred into a sterile $15 \mathrm{ml}$ falcon tube for further 
291 processing. The samples were centrifuged at 3500rpm for 30 minutes at room temperature. The

292 Middle semisolid hazy layer is used to prepare faecal smear for Modified Ziehl-Neelsen staining

293 (mZN staining) and nucleic acid extraction for molecular studies.

294 Nucleic Acid extraction

295 RNA Extraction from Cryptosporidium

296 TRizol reagent (Cat\# 9108) based protocol was used for RNA extraction of Cryptosporidium.

297 For this $200 \mu \mathrm{l}$ of the processed faecal sample was reconstituted in $900 \mu 1$ of TRizol reagent in a

$2982 \mathrm{ml}$ of micro-centrifuge tube and vortexed at high speed for 30 seconds followed by incubation

299 at 10 minutes for room temperature. The mixture is further spiked with $200 \mu 1$ chilled chloroform

300 and briefly vortexed for 30 seconds followed by spin at $13000 \mathrm{rpm}$ at $4{ }^{\circ} \mathrm{C}$ for 15 minutes. The

301 clear supernatant was collected in new micro-centrifuge tube (without touching the interface) and

302 then equal volume chilled isopropanol is topped-up and allowed to precipitate for 30 minutes at

$3034{ }^{\circ} \mathrm{C}$. The sample mixture was centrifuged again at $13000 \mathrm{rpm}$ for 15 minutes at $4^{\circ} \mathrm{C}$. The

304 supernatant was discarded without disturbing the pellet and reconstituted with $1 \mathrm{ml}$ chilled $70 \%$

305 ethanol to wash the pellet by centrifugation at $10000 \mathrm{rpm}$ for 5 minutes at room temperature.

306 Repeated this step for again and carefully discarded the supernatant and the residual solvent was

307 aspirated with the aid of $10 \mu 1$ micropipette to obtain moist-free pellet. The Pellet is further air

308 dried for 3-5 minutes at room temperature and reconstituted in $30 \mu 1$ of diethyl pyrocarbonate

309 (DEPC) treated water. The freshly extracted RNA was quantified by mixing with Quantifluor

310 RNA dye (Cat\# E3310) using Quantus Fluorometer® (Promega Technologies, Madison, USA)

311 as per the manufacturer's protocol.

\section{2 cDNA Synthesis}


313 The quantified RNA was converted into copy DNA (cDNA) using Primescript ${ }^{\mathrm{TM}} 1^{\text {st }}$ strand

314 cDNA synthesis kit (TaKaRa, Japan). $1^{\text {st }}$ Reaction Mixture was prepared by adding $8.0 \mu 1$ of

315 RNA $(1.0 \mu \mathrm{g} /$ concentration adjusted to $125.0 \mathrm{ng} / \mu \mathrm{l}), 1.0 \mu \mathrm{l}$ of Random Primer and $1.0 \mu \mathrm{l}$ of $10 \mathrm{mM}$

$316 \mathrm{dNTP}$ Mix and incubated at $65^{\circ} \mathrm{C}$ for $5 \mathrm{~min}$ and snap chilled in ice. $2^{\text {nd }}$ Reaction Mixture was

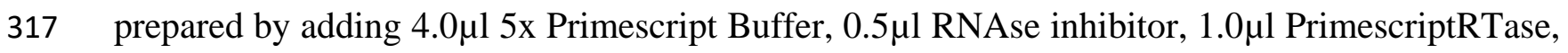

$3184.5 \mu 1$ RNAase free water in new micro-centrifuge tubes. The $1^{\text {st }}$ mixture the $2^{\text {nd }}$ mixture were

319 mixed in a new $0.2 \mathrm{ml}$ PCR tube incubated in thermal cycler for reverse transcription at following

320 conditions as per the thermal graph illustrated below.

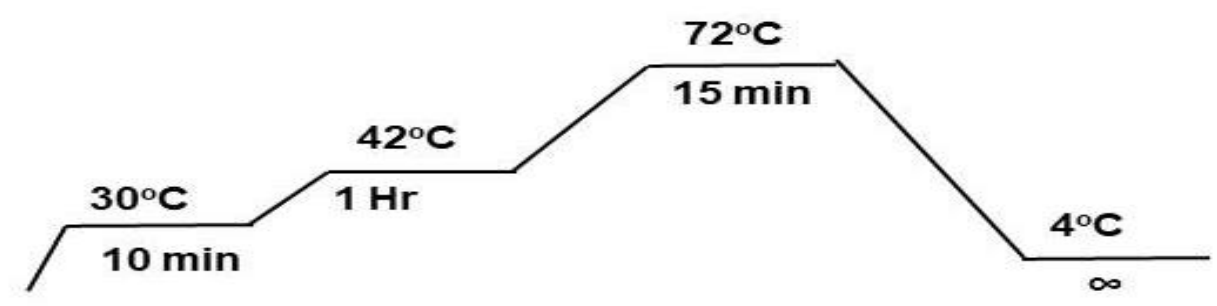

322 FIG 8 Cyclic conditions for cDNA synthesis in thermal cycler (Techne, TC 4000)

\section{DNA Extraction from Cryptosporidium}

\section{DNA extraction}

325 DNA extraction was also done for all the samples using the Wizard® Genomic DNA

326 Purification Kit according to the manufacturer's protocol (Cat\#A1120, Promega USA).The

327 eluted DNA was quantified by Quantus ${ }^{\mathrm{TM}}$ Fluorometer® (Cat\# E6150 Promega Technologies,

328 Madison, USA) as per the manufacturer's protocol and stored at $-20{ }^{\circ} \mathrm{C}$ for further use. 
Real time PCR primers and probes (Table 1) were designed using the BioEdit software program version 7.0.5.3 (Hall, 2011), by aligning FASTA sequences of various available strains of Cryptosporidium sequences from GenBank (National Center for Biotechnology Information [NCBI]; http://www.ncbi.nlm.nih.gov/GenBank/). The primer sequences picked were further analysed using Oligo Analyzer software for binding and thermodynamic properties. Primer and probe sequences were then checked for cross-reactions with non-targeted sequences on the GenBank database using the Basic Local Alignment Search Tool (BLAST)

337 (http://www.ncbi.nlm.nih .gov/blast/Blast.cgi) if any to rule out non-specific binding. Similarly probes were designed by the alignment of COWP gene and 18ssu rRNA gene sequences according to the recommendations and general guidelines (Proudnikov et al., 2003). Reporter dyes FAM (Fluorescein amidites) and HEX (Hexachloro-fluorescein) were conjugated at 5'end of probe for COWP and 18ssu rRNA genes respectively while BHQ -1 (Black Hole Quencher)

342 used as quencher dye at $3^{\prime}$ end for both the probes. Primers and TaqMan® probes were 343 synthesised commercially (Integrated DNA Technologies, Inc. 1710 Commercial Park 344 Coralville, Iowa 52241 USA).

\section{a. TTTAGACGgTAGgGTATTGGCCTACCGTGGCXATGACGGGT}

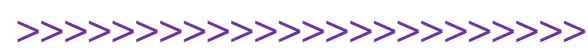




\section{AATCTGTCCTCCTGGATTCAATTTGTCAG}

Table 6 List of Primers and Probe used in TaqMan ${ }^{\circledR}$ based real-time PCR

\begin{tabular}{|c|c|c|c|c|c|}
\hline S.No & $\begin{array}{l}\text { Name of } \\
\text { Primer }\end{array}$ & Sequence $\left(5^{\prime} \rightarrow 3^{\prime}\right)$ & Length & Modification & Remark \\
\hline 1. & $\begin{array}{l}\text { Cryp_18s_ } \\
\text { F }\end{array}$ & $\begin{array}{l}\text { TAGACGGTAGGGTATTGGC } \\
\text { C }\end{array}$ & $20 \mathrm{nt}$ & Nil & $\begin{array}{l}\text { In-house } \\
\text { designed }\end{array}$ \\
\hline 2. & $\begin{array}{l}\text { Cryp_18s }{ }_{-} \\
\mathrm{R}\end{array}$ & $\begin{array}{l}\text { TGCTGCCTTCCTTAGATGT } \\
\text { GG }\end{array}$ & $21 \mathrm{nt}$ & Nil & \\
\hline 3. & Cryp_18s_ & TAGGGTTCGATTCCGGAGA & $24 \mathrm{nt}$ & 5'-HEX, & \\
\hline
\end{tabular}




\begin{tabular}{|c|c|c|c|c|}
\hline & Probe & GGGAG & & 3'-BHQ1 \\
\hline 4. & $\begin{array}{l}\text { COWP_new_ } \\
\text { F }\end{array}$ & $\begin{array}{l}\text { ATCCAGAATGTCCTCCAGG } \\
\text { CAC }\end{array}$ & $22 \mathrm{nt}$ & NIL \\
\hline 5. & $\begin{array}{l}\text { COWP_new_ } \\
\mathrm{R}\end{array}$ & $\begin{array}{l}\text { GACAAATTGAATCCAGGAG } \\
\text { GACAG }\end{array}$ & $24 \mathrm{nt}$ & NIL \\
\hline 6. & $\begin{array}{l}\text { COWP }_{-} \\
\text {Probe }\end{array}$ & $\begin{array}{l}\text { TGATACCGTTTGTCCTTCTG } \\
\text { G }\end{array}$ & $20 \mathrm{nt}$ & $\begin{array}{l}\text { 5'- 6FAM } \\
\text { 3'-BHQ1 }\end{array}$ \\
\hline
\end{tabular}

364 To check the workability each of the newly designed $18 s s u$ rRNA and COWP primers, conventional PCR was performed by following standard PCR reaction conditions. The

366 conventional PCR was performed separately for the genes in a $25 \mu$ l volume with $12.5 \mu 12 \mathrm{x}$

367 Emerald GT amp master mix (TaKaRa, Cat\# RR310A) along with 10 picomole of each of the

368 forward and reverse primers for the respective genes, $1 \mu 1$ of DNA template and made up the total

369 volume with PCR grade water. All the components were mixed gently and amplification was

370 carried out in thermal cycler (Techne, TC 4000) as per the thermal graph below.

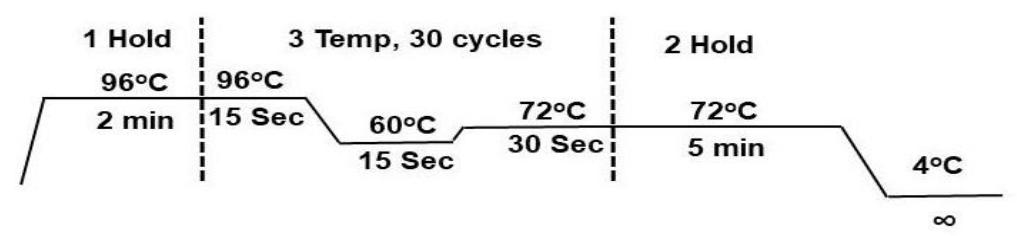

372 FIG 9 Cyclic conditions for gradient PCR in thermal cycler (Techne, TC 4000) 
373 Further the respective amplicons for the two genes were subjected to gel electrophoresis in $2.0 \%$

374 agarose TAE gel stained with Ethidium bromide along with 100bp DNA ladder. Electrophoresis

375 was carried out at a constant voltage of $100 \mathrm{~V}$ for 45 minutes. The DNA products were

376 visualized under the UV trans-illuminator and photographed using gel documentation system.

377 DNA duplex TaqMan ${ }^{\circledR}$ probe real time PCR

378 After confirmation by conventional PCR, the primers and newly designed respective probes

379 (18ssu rRNA and COWP) were analysed for its proper binding using DNA-based duplex

380 TaqMan® probe real time PCR. The real time PCR master mix was assembled in duplicates for

381 each sample in a final reaction volume of $25 \mu 1$ in 8 strip PCR tubes with optically compatible

382 caps assayed in the real-time thermal cycler (CFX96 Real time PCR system ${ }^{\circledR}$, Bio-Radwith the 383 reagent preparation (Table 7) and thermal conditions as mentioned below.

384 Table 7 Concentration and volume of reagents used in DNA duplex TaqMan ${ }^{\circledR}$ probe real time 385 PCR

\begin{tabular}{|c|c|c|c|c|}
\hline $\begin{array}{l}\text { S.N } \\
\text { o }\end{array}$ & \multicolumn{2}{|l|}{ Reagent } & Volume & Conc. used \\
\hline 1. & \multicolumn{2}{|c|}{ Premix Ex Taq Probe qPCR Master Mix } & $12.5 \mu \mathrm{l}$ & $2 x$ \\
\hline \multirow{3}{*}{2.} & \multirow{3}{*}{$C O W P(\mathrm{FAM})$} & Forward primer & $0.80 \mu \mathrm{l}$ & $(8 \mathrm{pmol} / \mu \mathrm{l})$ \\
\hline & & Reverse primer & $0.80 \mu \mathrm{l}$ & $(8 \mathrm{pmol} / \mu \mathrm{l})$ \\
\hline & & Probe & $1.0 \mu \mathrm{l}$ & $(10 \mathrm{pmol} / \mu \mathrm{l})$ \\
\hline \multirow{2}{*}{3.} & \multirow{2}{*}{$\begin{array}{l}\text { l88ssu } \quad r R N A \\
(\mathrm{HEX})\end{array}$} & Forward primer & $0.4 \mu 1$ & $(4 \mathrm{pmol} / \mu \mathrm{l})$ \\
\hline & & Reverse primer & $0.4 \mu \mathrm{l}$ & $(4 \mathrm{pmol} / \mu \mathrm{l})$ \\
\hline
\end{tabular}




\begin{tabular}{|l|l|l|l|}
\hline & Probe & $0.4 \mu \mathrm{l}$ & $(4 \mathrm{pmol} / \mu \mathrm{l})$ \\
\hline 5. & Template DNA & $3.0 \mu \mathrm{l}$ & $(\sim 5 \mathrm{ng})$ \\
\hline 6. & Nucleus Free Water & $5.7 \mu \mathrm{l}$ & - \\
\hline Total & $\mathbf{2 5 \mu l}$ & \\
\hline
\end{tabular}

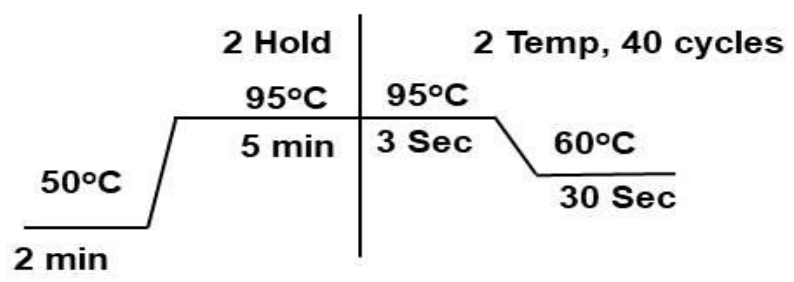

FIG 10 Cyclic conditions for DNA duplex TaqMan ${ }^{\circledR}$ probe real time PCR

\section{Standardization of Simplex Probe based reverse transcription real-time PCR:}

Real Time PCR protocol was separately standardized for COWP and $18 s s u$ rRNA probe and primers using positive control cDNA. Probe qPCR master mix (TaKaRa, Japan) was used for the quantitative analysis of COWP and 18ssu rRNA genes. Primers and probes were titrated serially starting from 2pmol/reaction, 4pmol/reaction, $6 \mathrm{pmol} /$ reaction, $8 \mathrm{pmol} / \mathrm{reaction}$ to $10 \mathrm{pmol} / \mathrm{reaction}$ for COWP and 18ssu rRNA genes individually (Table 8). All the reactions were performed in duplicates in Premix Ex Taq Probe qPCR Master Mix (2X) (TaKaRa, Japan Cat\#RR390) in a

396 final volume of $25 \mu 1$ per tube in a CFX96 Real time PCR system ${ }^{\circledR}$ (Bio-Rad) with the thermal 397 conditions as described below. The reaction also included positive control (PC) and No template Control (NTC) for interpretation of the results. 
Table 8 Optimization and standardization of Probe and primer dilutions with checkerboard titration method for Simplex real time PCR of COWP and 18ssu rRNA genes

\begin{tabular}{|c|c|c|c|c|c|c|}
\hline Targeted & \multicolumn{6}{|l|}{ Dilution } \\
\hline $\begin{array}{l}\text { cowp } \\
\text { Probe } \\
\text { dilution }\end{array}$ & $\begin{array}{l}\text { Forward and Reverse } \\
\text { Primer } \\
\text { (constant) }\end{array}$ & \multicolumn{5}{|c|}{10 pmol each as constant } \\
\hline dilution & Probe (titration) & 2pmol & 4 pmol & $6 \mathrm{pmol}$ & 8pmol & 10pmol \\
\hline \multirow[t]{2}{*}{$\begin{array}{l}\text { cowp } \\
\text { Primer } \\
\text { dilution }\end{array}$} & $\begin{array}{l}\text { Forward and Reverse } \\
\text { Primer } \\
\text { (titration) }\end{array}$ & $2 \mathrm{pmol}$ & $4 \mathrm{pmol}$ & $6 \mathrm{pmol}$ & 8pmol & 10pmol \\
\hline & $\begin{array}{l}\text { Probe } \\
\text { (constant) }\end{array}$ & \multicolumn{5}{|c|}{10 pmol constant } \\
\hline \multirow[t]{2}{*}{$\begin{array}{l}\text { I8ssu rRNA } \\
\text { Probe } \\
\text { dilution }\end{array}$} & $\begin{array}{l}\text { Forward and Reverse } \\
\text { Primer } \\
\text { (constant) }\end{array}$ & \multicolumn{5}{|c|}{10 pmol each as constant } \\
\hline & Probe (titration) & $2 \mathrm{pmol}$ & $4 \mathrm{pmol}$ & 6pmol & 8pmol & 10pmol \\
\hline \multirow{2}{*}{$\begin{array}{l}\text { I8ssu rRNA } \\
\text { Primer } \\
\text { dilution }\end{array}$} & $\begin{array}{l}\text { Forward and Reverse } \\
\text { Primer } \\
\text { (titration) }\end{array}$ & 2pmol & $4 p m o l$ & $6 \mathrm{pmol}$ & 8pmol & 10pmol \\
\hline & $\begin{array}{l}\text { Probe } \\
\text { (constant) }\end{array}$ & \multicolumn{5}{|c|}{10 pmol constant } \\
\hline
\end{tabular}


402 Table 9 Concentration and volume of reagents used in Probe based real-time PCR

\begin{tabular}{|l|l|c|c|}
\hline S.No & Reagent & Volume & Conc. Used \\
\hline 1 & Premix Ex Taq Probe qPCR Master & $12.5 \mu \mathrm{l}$ & $2 \mathrm{x}$ \\
2 & Forward primer & $1.25 \mu \mathrm{l}$ & $(10 \mathrm{pmol} / \mu \mathrm{l})$ \\
3 & Reverse primer & $1.25 \mu \mathrm{l}$ & $(10 \mathrm{pmol} / \mu \mathrm{l})$ \\
4 & Probe & $1.25 \mu \mathrm{l}$ & $(10 \mathrm{pmol} / \mu \mathrm{l})$ \\
5 & Template & $1.0 \mu \mathrm{l}$ & $(\sim 5 \mathrm{ng})$ \\
6 & Nucleus Free Water & $7.75 \mu \mathrm{l}$ & - \\
\hline
\end{tabular}

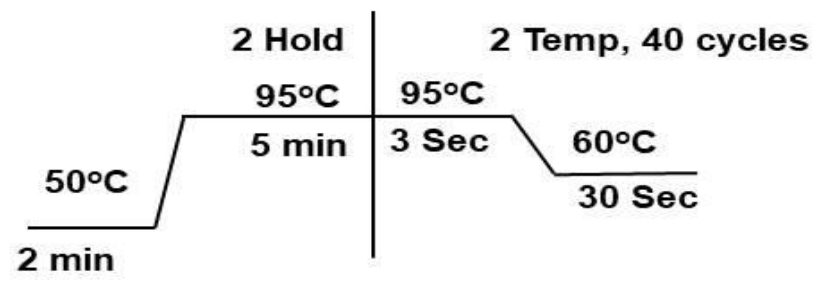

404

405 FIG 1 Cyclic conditions for primers and probe optimization protocol in TaqMan ${ }^{\circledR}$ based real-

406 time PCR (qPCR)

407

408

Duplex probe Real time PCR

409 Standardization and optimization of primer, probe \& template for Duplex reverse transcription TaqMan ${ }^{\circledR}$ Probe Real time PCR for Cryptosporidia: 
411 Finally, after conducting a series of experiments on the primer and probe standardization, the

412 same assay was subjected to duplex mode using RNA as target. As per the previous section on

413 DNA based duplex PCR, a similar titration technique is followed but this time with positive

414 cDNA prepared from oocysts of Cryptosporidium.

415 Table 10 Optimization of primers, probes and template dilutions with respective constants and variables concentration for multiplex real time PCR of all three parameters and both the genes.

\begin{tabular}{|c|c|c|c|}
\hline \multicolumn{2}{|l|}{ Targets } & COWP (FAM) & 18ssu rRNA (HEX) \\
\hline \multirow{3}{*}{ Probe titration } & $\begin{array}{l}\text { Primer }(\mathrm{F}+\mathrm{R}) \\
(\text { constant })\end{array}$ & $10 \mathrm{pmol} / \mu \mathrm{l}$ & $10 \mathrm{pmol} / \mu \mathrm{l}$ \\
\hline & $\begin{array}{l}\text { Probe } \\
\text { (Variable) }\end{array}$ & $\begin{array}{l}10 \mathrm{pmol} / \mu \mathrm{l}, 8 \mathrm{pmol} / \mu \mathrm{l}, 6 \\
\mathrm{pmol} / \mu \mathrm{l},\end{array}$ & $\begin{array}{l}10 \mathrm{pmol} / \mu \mathrm{l}, 8 \mathrm{pmol} / \mu \mathrm{l}, 6 \\
\mathrm{pmol} / \mu \mathrm{l}, 4 \mathrm{pmol} / \mu \mathrm{l}, \\
2 \mathrm{pmol} / \mu \mathrm{l}\end{array}$ \\
\hline & $\begin{array}{l}\text { Template } \\
\text { (constant) }\end{array}$ & $1 \mu l$ & $1 \mu 1$ \\
\hline \multirow{3}{*}{ Primer titration } & $\begin{array}{l}\text { Primer }(\mathrm{F}+\mathrm{R}) \\
\text { (Variable) }\end{array}$ & $\begin{array}{l}10 \mathrm{pmol} / \mu 1,8 \mathrm{pmol} / \mu \mathrm{l}, 6 \\
\mathrm{pmol} / \mu \mathrm{l}, \\
2 \mathrm{pmol} / \mu \mathrm{l}\end{array}$ & $\begin{array}{l}10 \mathrm{pmol} / \mu \mathrm{l}, \quad 8 \mathrm{pmol} / \mu \mathrm{l}, 6 \\
\mathrm{pmol} / \mu \mathrm{l}, 4 \mathrm{pmol} / \mu \mathrm{l} \\
2 \mathrm{pmol} / \mu \mathrm{l}\end{array}$ \\
\hline & $\begin{array}{l}\text { Probe } \\
\text { (constant) }\end{array}$ & $10 \mathrm{pmol} / \mu \mathrm{l}$ & $10 \mathrm{pmol} / \mu \mathrm{l}$ \\
\hline & Template & $1 \mu 1$ & $1 \mu l$ \\
\hline
\end{tabular}



optimization:

421 After standardization and optimization Duplex reverse transcription TaqMan ${ }^{\circledR}$ Probe Real time 422 PCR for Cryptosporidia was performed with total reaction volume of $25 \mu 1$ with the same thermal 423 cyclic conditions as above. Final reaction concentration of primer, probe and template for COWP 424 (FAM) and 188ssu rRNA (HEX) genes are given in table below.

425 Table 11 Final concentrations of primer, probe and templates in multiplex TaqMan ${ }^{\circledR}$ probe based 426 Real Time PCR reaction mix

\begin{tabular}{|l|l|l|l|l|}
\hline S.No & Reagent & Volume & Conc. used \\
\hline 1. & $\begin{array}{l}\text { Premix Ex Taq Probe qPCR } \\
\text { Master Mix }\end{array}$ & $12.5 \mu \mathrm{l}$ & $2 \mathrm{x}$ \\
\hline 2. & COWP(FAM) & Forward primer & $0.80 \mu 1$ & $(8 \mathrm{pmol} / \mu \mathrm{l})$ \\
\hline
\end{tabular}




\begin{tabular}{|l|l|l|l|l|}
\hline & & Reverse primer & $0.80 \mu \mathrm{l}$ & $(8 \mathrm{pmol} / \mu \mathrm{l})$ \\
\hline $\mathbf{3}$ & & Probe & $1.0 \mu \mathrm{l}$ & $(10 \mathrm{pmol} / \mu \mathrm{l})$ \\
\hline & $(\mathrm{HEX})$ & Forward primer & $0.4 \mu \mathrm{l}$ & $(4 \mathrm{pmol} / \mu \mathrm{l})$ \\
\hline 5. & Template & Reverse primer & $0.4 \mu \mathrm{l}$ & $(4 \mathrm{pmol} / \mu \mathrm{l})$ \\
\hline 6. & Nucleus Free Water & $0.4 \mu \mathrm{l}$ & $(4 \mathrm{pmol} / \mu \mathrm{l})$ \\
\hline Total & & $3.0 \mu \mathrm{l}$ & $(\sim 5 \mathrm{ng})$ \\
\hline
\end{tabular}

Limit of detection assays for the Duplex Probe Real time PCR:

To know the limit of detection (LOD) and other variables including regression coefficient, $\mathrm{Y}$ -

431 intercept, efficiency etc, of the current assay, a copy number based standard dilution was

432 conducted by absolute quantification mode. Positive DNA amplicons generated by conventional

433 reverse transcription PCR for COWP and 18ssu rRNA genes respectively were gel purified using

434 Sigma GenElute gel extraction kit (Cat\# NA1111) following manufacturer's protocol. The gel

435 purified DNA were further subjected to quantification by mixing with QuantiFluor ONE dsDNA

436 System, (Cat\# E4871 Promega) and measured in Quantus ${ }^{\mathrm{TM}}$ Fluorometer® (Cat\# E6150,

437 Promega) as per the manufacturer's protocol. Copy number was derived based on the amplicon

438 length (bp) and concentration of the purified amplicon by using the copy number formula

439 available in the online tool (https://cels.uri.edu/gsc/cndna.html) as given below 
440 number of copies $=$ concentration $($ in $n g) x \frac{6.022 \times 10^{23}}{\text { length }}$ of primer $x 1 \times 10^{9} \times 650$. The real

441 time PCR conditions and master mix assembled for the LOD were the same as mentioned in the

442 previous section for duplex TaqMan probe real time PCR.

443 Duplex reverse transcription TaqMan probe based Quantitative real time pcr (dRT-qPCR)

\section{$444 \quad$ Relative quantification}

Relative quantification was performed to quantify the transcriptional fold change of COWP (Target gene) vis-à-vis the 18ssurRNA gene (Reference gene). Since 18ssurRNA gene was constitutively expressed in cryptosporidia, it was regarded as a reference or housekeeping gene in the current study. For this relative quantification assay, 4 numbers of neonatal goat kids

of less than one month of age were selected (based on screening from the 100 animals stock of same age group) for this study based on clinical signs (clinical status) like diarrhea, weakness and dehydration along with detection of positive oocysts in fecal mZN smear microscopy.

452 Similarly, a neonatal goat kid of same age which is apparently healthy (no signs of diarrhea, 453 dehydration, weakness, dullness etc.) but positive for cryptosporidial oocysts (carrier status) by 454 fecal microscopy has been selected as control animal for the study based on continuous screening 455 of healthy animals from a stock of 100 animals of same age group (<1month age). Further fecal 456 samples from the kids with clinical status (Unknown) and carrier status (Control) were subjected 457 to RNA extraction and cDNA synthesis as per the protocol described in the previous sections.

458 Reaction mix was prepared in duplicates for each of the sample using the master mix, probes, 459 primers, and nuclease free water as per the protocol described in previous sections (Table.No.6) 460 in duplex mode. No template control (NTC) and non-reverse transcription controls (NRT) were 461 also kept for interpretation of the results. The assay was performed as per the thermal conditions 
462 described in previous sections (Fig.4). The data analysis for gene expression studies was done

463 using the CFX-96 manager (CFX Real-time PCR system, Biorad ${ }^{\circledR}$, USA) using the $\Delta \Delta C q$

464 algorithm. The $\Delta \Delta \mathrm{Cq}$ method was done using the formula described by Livak and Schmittgen

465 (2001) for determining the relative expression (fold change) of target genes of cryptosporida in

466 total RNA isolated from fecal samples of neonatal goat kids used in the current study. In this

467 method, the $\Delta \mathrm{Cq}$ (cycle threshold) values for each cryptosporidia suspected goat kids were

468 figured out by subtracting 18ssurRNA Cq values from Cq values of gene of interest (in our study

469 it is COWP). The average $\Delta \mathrm{Cq}$ for samples from control group (healthy cryptosporidia oocyst

470 carriers with no clinical signs) are used as calibrator ( $\Delta \mathrm{Cq}$ calibrator).

Further $\Delta \Delta \mathrm{Cq}$ values were computed by subtracting the average $\Delta \mathrm{Cq}$ of calibrator

472 (healthy cryptosporidia oocyst carriers with no clinical signs) group from average $\Delta \mathrm{Cq}$ of

473 unknown animals (clinically and microscopically positive for cryptosporidia).

$474 \Delta \Delta \mathrm{Cq}=\Delta \mathrm{Cq}($ Unknown $)-\Delta \mathrm{Cq}($ control $)$

where, $\Delta \mathrm{Cq}($ unknown $)=\mathrm{Cq}($ target gene; COWP $)-\mathrm{Cq}($ reference gene; 18 ssurRNA $)$

476 Therefore,

$477 \Delta \Delta \mathrm{Cq}=[\mathrm{Cq}($ target, unknown $)-\mathrm{Cq}($ ref, unknown $)]-[\mathrm{Cq}($ target, control $)-\mathrm{Cq}($ ref, control $)]$

479 calculated by taking $\Delta \Delta \mathrm{Cq}$ as negative exponent of two, i.e., $2^{-\Delta \Delta \mathrm{Cq}}$. The fold change thus

480 derived represents the gene expression normalized to an endogenous reference or house-keeping

481 gene (18ssurRNA) and relative to the control. A fold change of 1 in control group was used as a

482 baseline for comparison with unknown animals (clinically and microscopically positive for 483 cryptosporidia). 


\section{REFERENCES}

485

486

487

488

489

490

491

492

493

494

495

496

497

498

499

500

501

502

503

504
1. Inungu JN, Morse AA, Gordon C. 2000. Risk factors, seasonality, and trends of cryptosporidiosis among patients infected with human immunodeficiency virus. T Am J Trop Med Hyg 62: 384-387. https://doi.org/10.4269/ajtmh.2000.62.384.

2. White A. C. J. 2010 Cryptosporidiosis and the ears of the hippopotamus. Clin. Infect. Dis. 50, 1373-1374. https://doi.org/10.1086/652141.

3. Díaz-Lee A, Mercado R, Onuoha EO, Ozaki LS, Muñoz P, Muñoz V, Martínez FJ, Fredes F. 2011. Cryptosporidium parvum in diarrheic calves detected by microscopy and identified by immunochromatographic and molecular methods. Vet Parasitol 176:139144. https://doi.org/10.1016/j.vetpar.2010.11.001.

4. Wang ZD, Liu Q, Liu HH, Li S, Zhang L, Zhao YK, Zhu XQ. 2018. Prevalence of Cryptosporidium, microsporidia and Isospora infection in HIV-infected people: a global systematic review and meta-analysis. Parasites Vectors 11:28. https://doi.org/10.1186/s13071-017-2558-x.

5. O'Donoghue PJ. 1995. Cryptosporidium and cryptosporidiosis in man and animals. International journal for parasitology. Int J Parasitol 25(2):139-195. https://doi.org/10.1016/0020-7519(94)E0059-V.

6. Checkley W, White Jr AC, Jaganath D, Arrowood MJ, Chalmers RM, Chen XM, Fayer R, Griffiths JK, Guerrant RL, Hedstrom L, Huston CD. 2015. A review of the global burden, novel diagnostics, therapeutics, and vaccine targets for cryptosporidium. Lancet Infect Dis 15(1):85-94. https://doi.org/10.1016/S1473-3099(14)70772-8. 
7. Paul S, Sharma DK, Boral R, Mishra AK, Nayakwadi S, Banerjee PS, Pawaiya RS. 2014. Cryptosporidiosis in goats: a review. Adv Anim Vet Sci. 2014 2(3S):49-54. http://dx.doi.org/10.14737/journal.aavs/2014/2.3s.49.54.

508

509

8. Mishra AK, Singh DD, Kumar N, Kumarsen G, Paul S, Kumar A. 2020. Role of Bacterial and Parasitic Pathogens in Occurrence of Neonatal Diarrhoea in Goat-Kids. J Anim Res 10(3):389-395. http://dx.doi.org/10.30954/2277-940X.03.2020.9.

9. Robertson LJ, Campbell AT, Smith HV. 1992. Survival of Cryptosporidium parvum oocysts under various environmental pressures. Appl Environ Microbiol 58(11):34943500. https://doi.org/10.1128/aem.58.11.3494-3500.1992.

10. Fayer RO, Trout JA, Nerad TH. 1996. Effects of a wide range of temperatures on infectivity of Cryptosporidium parvum oocysts. J Eukaryot Microbiol 43(5):64S. https://doi.org/10.1111/j.1550-7408.1996.tb04995.x.

11. Fujino T, Matsui T, Kobayashi F, Haruki K, Yoshino Y, Kajima J, Tsuji M. 2002. The effect of heating against Cryptosporidium oocysts. J Vet Med Sci 64:199-200. https://doi.org/10.1292/jvms.64.199.

12. Cacciò SM, Putignani L. 2014. Epidemiology of human cryptosporidiosis. InCryptosporidium: parasite and disease. Springer, Vienna 43-79. https://doi.org/10.1007/978-3-7091-1562-6_2.

13. Mary C, Chapey E, Dutoit E, Guyot K, Hasseine L, Jeddi F, Menotti J, Paraud C, Pomares C, Rabodonirina M, Rieux A. 2013. Multicentric evaluation of a new real-time PCR assay for quantification of Cryptosporidium spp. and identification of Cryptosporidium parvum and Cryptosporidium hominis. J Clin Microbiol 51(8):25562563. https://doi.org/10.1128/JCM.03458-12. 
14. Khalil S, Mirdha BR, Paul J, Panda A, Makharia G, Chaudhry R, Bhatnagar S. 2016. Development and evaluation of molecular methods for detection of Cryptosporidium spp. in human clinical samples. Exp Parasitol 170:207-213. https://doi.org/10.1016/j.exppara.2016.10.001.

15. Parčina M, Reiter-Owona I, Mockenhaupt FP, Vojvoda V, Gahutu JB, Hoerauf A, Ignatius R. 2018. Highly sensitive and specific detection of Giardia duodenalis, Entamoeba histolytica, and Cryptosporidium spp. in human stool samples by the BD MAX $^{\mathrm{TM}}$ Enteric Parasite Panel. Parasitol Res 117(2):447-51. https://doi.org/10.1007/s00436-017-5720-7.

16. Shin JH, Lee SE, Kim TS, Ma DW, Cho SH, Chai JY, Shin EH. 2018. Development of molecular diagnosis using multiplex real-time PCR and T4 phage internal control to simultaneously detect Cryptosporidium parvum, Giardia lamblia, and Cyclospora cayetanensis from human stool samples. Korean J Parasitol (5):419. https://dx.doi.org/10.3347\%2Fkjp.2018.56.5.419.

17. Pomari E, Piubelli C, Perandin F, Bisoffi Z. 2019. Digital PCR: A new technology for diagnosis of parasitic infections. Clin Microbiol Infect 25(12):1510-1516. https://doi.org/10.1016/j.cmi.2019.06.009.

18. Paulos S, Saugar JM, de Lucio A, Fuentes I, Mateo M, Carmena D. 2019. Comparative performance evaluation of four commercial multiplex real-time PCR assays for the detection of the diarrhoea-causing protozoa Cryptosporidium hominis/parvum, Giardia duodenalis and Entamoeba histolytica. PLoS One 14(4):0215068. https://doi.org/10.1371/journal.pone.0215068. 
19. Shaposhnik EG, Abozaid S, Grossman T, Marva E, On A, Azrad M, Peretz A. 2019. The prevalence of Cryptosporidium among children hospitalized because of gastrointestinal symptoms and the efficiency of diagnostic methods for Cryptosporidium. Am. J Trop Med Hyg 101(1):160. https://dx.doi.org/10.4269\%2Fajtmh.19-0057.

20. Köller T, Hahn A, Altangerel E, Verweij JJ, Landt O, Kann S, Dekker D, May J, Loderstädt U, Podbielski A, Frickmann H. 2020. Comparison of commercial and inhouse real-time PCR platforms for 15 parasites and microsporidia in human stool samples without a gold standard. Acta Trop 207:105516. https://doi.org/10.1016/j.actatropica.2020.105516.

21. Mergen K, Espina N, Teal A, Madison-Antenucci S. 2020. Detecting Cryptosporidium in Stool Samples Submitted to a Reference Laboratory. Am J Trop Med Hyg 103(1):421. https://dx.doi.org/10.4269\%2Fajtmh.19-0792.

22. Frickmann H, Hoffmann T, Köller T, Hahn A, Podbielski A, Landt O, Loderstädt U, Tannich E. 2021. Comparison of five commercial real-time PCRs for in-vitro diagnosis of Entamoeba histolytica, Giardia duodenalis, Cryptosporidium spp., Cyclospora cayetanensis, and Dientamoeba fragilis in human stool samples. Travel Med Infect Dis 102042. https://doi.org/10.1016/j.tmaid.2021.102042.

23. Wang Y, Zhang B, Li J, Yu S, Zhang N, Liu S, Zhang Y, Li J, Ma N, Cai Y, Zhao Q. 2021. Development of a quantitative real-time PCR assay for detection of Cryptosporidium spp. infection and threatening caused by Cryptosporidium parvum subtype IIdA19G1 in diarrhea calves from northeastern China. Vector Borne Zoonotic Dis 21(3):179-90. https://doi.org/10.1089/vbz.2020.2674. 

2012. A comparison of two approaches to extracting Cryptosporidium DNA from human stools as measured by a real-time PCR assay. J Microbiol Methods 89(1):38-40. https://doi.org/10.1016/j.mimet.2012.02.006.

576

25. Valeix N, Costa D, Basmaciyan L, Valot S, Vincent A, Razakandrainibe R, RobertGangneux F, Nourrisson C, Pereira B, Fréalle E, Poirier P. 2020. Multicenter comparative study of six Cryptosporidium parvum DNA extraction protocols including mechanical pretreatment from stool samples. Microorganisms 8(9):1450. https://www.mdpi.com/2076-2607/8/9/1450\#.

26. Claudel L, Valeix N, Basmaciyan L, Pereira B, Costa D, Vincent A, Valot S, Favennec L, Dalle F. 2021. Comparative study of eleven mechanical pretreatment protocols for Cryptosporidium parvum DNA extraction from stool samples. Microorganisms 9(2):297. https://www.mdpi.com/2076-2607/9/2/297\#.

27. Hoffmann T, Hahn A, Verweij JJ, Leboulle G, Landt O, Strube C, Kann S, Dekker D, May J, Frickmann H, Loderstädt U. 2021. Differing effects of standard and harsh nucleic acid extraction procedures on diagnostic helminth real-time PCRs applied to human stool samples. Pathogens. 10(2):188. https://www.mdpi.com/2076-0817/10/2/188\#.

28. Fontaine M, Guillot E. 2002. Development of a TaqMan quantitative PCR assay specific for Cryptosporidium parvum. FEMS Microbiol Lett 214(1):13-17. https://doi.org/10.1111/j.1574-6968.2002.tb11318.x.

29. Guy RA, Payment P, Krull UJ, Horgen PA. 2003. Real-time PCR for quantification of Giardia and Cryptosporidium in environmental water samples and sewage. Appl Environ Microbiol 69(9):5178-5185. https://doi.org/10.1128/AEM.69.9.5178-5185.2003. 
30. Jothikumar N, Da Silva AJ, Moura I, Qvarnstrom Y, Hill VR. 2008. Detection and differentiation of Cryptosporidium hominis and Cryptosporidium parvum by dual TaqMan assays. $\mathbf{J}$ Med Microbiol 57(9):1099-1105. https://doi.org/10.1099/jmm.0.2008/001461-0.

31. Verweij JJ, Stensvold CR. 2014. Molecular testing for clinical diagnosis and epidemiological investigations of intestinal parasitic infections. Clin Microbiol Rev 27(2):371-418. https://doi.org/10.1128/CMR.00122-13.

32. Shrivastava AK, Kumar S, Mohakud NK, Suar M, Sahu PS. 2017. Multiple etiologies of 603 infectious diarrhea and concurrent infections in a pediatric outpatient-based screening study in Odisha, India. Gut Pathog 9(1):1-2. https://doi.org/10.1186/s13099-017-0166-0. tool for delineating species within Cryptosporidium. J Parasitol 89(2):399-402. https://doi.org/10.1645/0022-3395(2003)089[0399:MINART]2.0.CO;2.

34. Hassan EM, Örmeci B, DeRosa MC, Dixon BR, Sattar SA, Iqbal A. 2021. A review of Cryptosporidium spp. and their detection in water. Water Sci and Technol 83(1):1-25. https://doi.org/10.2166/wst.2020.515. Cryptosporidium and Giardia as foodborne zoonoses. Veterinary parasitology, 149(1-2), 29-40. https://doi.org/10.1016/j.vetpar.2007.07.015. 8(1):2. https://dx.doi.org/10.4103\%2Ftp.TP_34_17. 
37. O'Leary JK, Sleator RD, Lucey B. 2021. Cryptosporidium spp. diagnosis and research in the 21st century. Food Waterborne Parasitol 24:00131. https://doi.org/10.1016/j.fawpar.2021.e00131.

38. Omoruyi BE, Nwodo UU, Udem CS, Okonkwo FO. 2014. Comparative diagnostic techniques for Cryptosporidium infection. Molecules 19(2):2674-2683. https://doi.org/10.3390/molecules19022674.

39. Anceno AJ, Katayama H, Houpt ER, Chavalitshewinkoon-Petmitr P, Chuluun B, Shipin OV. 2007. IMS-free DNA extraction for the PCR-based quantification of Cryptosporidium parvum and Giardia lamblia in surface and waste water. J Environ Health Res 17(4):297-310. https://doi.org/10.1080/09603120701372573.

40. Staggs SE, Beckman EM, Keely SP, Mackwan R, Ware MW, Moyer AP, Ferretti JA, Sayed A, Xiao L, Villegas EN. 2013. The applicability of TaqMan-based quantitative real-time PCR assays for detecting and enumerating Cryptosporidium spp. oocysts in the environment. PloS one. 8(6):66562. https://doi.org/10.1371/journal.pone.0066562.

41. Costa D, Soulieux L, Razakandrainibe R, Basmaciyan L, Gargala G, Valot S, Dalle F, Favennec L. 2021. Comparative performance of eight PCR methods to detect cryptosporidium species. Pathogens 10(6):647. https://doi.org/10.3390/pathogens10060647.

42. A Escobedo, A., Almirall, P., J Robertson, L., MB Franco, R., Hanevik, K., Morch, K., \& Cimerman, S. (2010). Giardiasis: the ever-present threat of a neglected disease. Infectious Disorders-Drug Targets (Formerly Current Drug Targets-Infectious Disorders), 10(5), 329-348. https://doi.org/10.2174/187152610793180821. 
43. Youn S, Kabir M, Haque R, Petri Jr WA. 2009. Evaluation of a screening test for detection of Giardia and Cryptosporidium parasites. J Clin Microbiol 47(2):451-452. https://doi.org/10.1128/JCM.01736-08.

44. Johnson, A. M., Di Giovanni, G. D., \& Rochelle, P. A. (2012). Comparison of assays for sensitive and reproducible detection of cell culture-infectious Cryptosporidium parvum and Cryptosporidium hominis in drinking water. Applied and Environmental Microbiology, 78(1), 156-162. https://doi.org/10.1128/AEM.06444-11.

45. Schuurman T, Lankamp P, van Belkum A, Kooistra-Smid M, Van Zwet A. 2007. Comparison of microscopy, real-time PCR and a rapid immunoassay for the detection of Giardia lamblia in human stool specimens. Clin Microbiol Infec 13(12):1186-1191. https://doi.org/10.1111/j.1469-0691.2007.01836.x.

46. Xiao L. 2010. Molecular epidemiology of cryptosporidiosis: an update. Exp Parasitol 124(1):80-89. https://doi.org/10.1016/j.exppara.2009.03.018.

47. Farcas GA, Soeller R, Zhong K, Zahirieh A, Kain KC. 2006. Real-time polymerase chain reaction assay for the rapid detection and characterization of chloroquine-resistant Plasmodium falciparum malaria in returned travelers. Clin Infect Dis 42(5):622-627. https://doi.org/10.1086/500134.

48. Shokoples SE, Ndao M, Kowalewska-Grochowska K, Yanow SK. 2009. Multiplexed real-time PCR assay for discrimination of Plasmodium species with improved sensitivity for mixed infections. J Clin Microbiol 47(4):975-980. https://doi.org/10.1128/JCM.01858-08. 